Research, part of a Special Feature on Ecological Restoration in Northern Regions

\title{
Do the Principles of Ecological Restoration Cover EU LIFE Nature Cofunded Projects in Denmark?
}

\author{
Jonas Morsing $^{1}$, Sally Ida Frandsen ${ }^{1}$, Henrik Vejre $^{1}$ and Karsten Raulund-Rasmussen ${ }^{1}$
}

\begin{abstract}
Ecological restoration is becoming a main component in nature management; hence, its definitions and interpretations of the underlying principles are widely discussed. In Denmark, restoration has been implemented for decades, and the LIFE Nature program has contributed to several large-scale projects. Our aim was to indicate tendencies in Danish nature policy by analyzing a representative sample of nature management projects. Using qualitative document analyses of official reports, we investigated how well 13 LIFE Nature cofinanced projects undertaken in Denmark fit with the principles of ecological restoration, as formulated in the nine attributes of the Society for Ecological Restoration's Primer on Ecological Restoration, and based on the five myths of ecological restoration. Objectives of the analyzed projects were divided into three categories: conservation of a single or a group of species; restoration of set-aside areas, mainly on abandoned agricultural land; and habitat management of Natura 2000 areas. Despite this grouping, improvement in living conditions for certain species associated with specific nature types was in focus in all projects. No projects considered or fulfilled all nine attributes. It seems that attributes associated with fundamental requirements for the existence of target species or habitats were more often fulfilled than attributes associated with continuity of the ecosystem as a whole, which indicated a focus on ecosystem structures rather than on processes. We found that the two assumptions of a predictable single endpoint (the myth of the Carbon Copy) and that nature is controllable (the myth of Command and Control) were notably frequent in the Danish projects. Often, the target ecosystem was associated with a semicultural landscape, and management focused on keeping the vegetation low and preventing overgrowth of colonizing trees. The results indicated that nature policy in Denmark and the LIFE Nature program are based on a control paradigm, with the focus on structures rather than on processes. Further, the results revealed that the definition and interpretation of ecological restoration is ambiguous, and according to land use history, there is a need for concepts and approaches to be clearly defined.
\end{abstract}

Key Words: benchmark; ecological restoration; human impact; LIFE Nature; Natura 2000; nature policy; semicultural landscapes; SER attributes

\section{INTRODUCTION}

Ecological restoration has become more and more frequent in nature management around the world (e.g., Suding 2011). Though ecological restoration follows the overall guiding principle of reverting ecosystems to some kind of earlier and more desirable state, it covers a wide range of actions at many spatial scales and a wide range of incitements and goals. Ecological restoration has been practiced for decades, but attempts to formalize and define the concept have emerged only gradually in scientific communities. As a milestone in this effort, the Society for Ecological Restoration International (SER) published a primer in 2004 that defines ecological restoration as "the process of assisting the recovery of an ecosystem that has been degraded, damaged, or destroyed" (SER 2004). Parallel to this condensed definition, the primer presents nine descriptive attributes of ecological restoration, followed by a comprehensive introduction to the concept, for example, a glossary and a discussion of ecological restoration in comparison to related practices. Though the primer has been disputed, e.g., by Davis and Slobodkin (2004) and Winterhalder et al. (2004), it represents a thoroughly prepared approach, and has been used as a tool to evaluate restoration projects (e.g., Ruiz-Jaen and Aide 2005).
The discourse over the subject continued when Hilderbrand et al. (2005) highlighted conventional understanding of ecological restoration as often being "over-application of over-simplified" guiding principles or myths. The authors raised caution regarding a risk of failure when not addressing the complexity of systems or the uncertainty of future changes (Hilderbrand et al. 2005), e.g., by lack of system resilience. The five myths encompass (1) the myth of the Carbon Copy, where a single-state endpoint with predicted species assembly is expected, (2) the myth of the Field of Dreams, where the restoration activities are based on self organization and focus solely on physico-chemical conditions, (3) the myth of FastForwarding, with belief in repeatable successive ecosystem development pathways that can be accelerated, (4) the myth of the Cookbook, where methodologies are not site adapted, and (5) the myth of Command and Control and the Sisyphus Complex, which assume that humans can actively control ecosystems to manage for particular ecosystem states indefinitely into the future. The most recent discussions continue to deal with the incorporation of future changes in restoration projects, e.g., from land use to climatic change and differences inherent to spatial scale in the goal setting of projects (Hobbs 2007, Hobbs and Cramer 2008), which have 
led to the proposal of a more open-ended approach in ecological restoration (Hughes et al. 2011).

Numerous restoration projects aimed at improving nature values and environmental standards have been implemented in Denmark within the last three decades (Pedersen 2010): they range from small-scale private projects, such as afforestation (Madsen 2003), to large-scale national projects, such as the remeandering of the Skjern River and recreation of its associated 2200-ha floodplain (Oxboel State Forest District 2005, Pedersen et al. 2007). The LIFE Nature program (EC 2011a) has played an essential role in the financing of many large-scale projects (COWI 2009a), and projects implemented under this program may be considered as a representative sample of nature management projects in Denmark.

The Danish landscape is highly cultivated, as is typical for lowland northwestern Europe. Some 65\% of the land territory is arable land, and the remaining land area comprises strongly cultivated forests, urban areas, and minor patches of permanent grassland and other seminatural areas (EUROSTAT 2011). Relatively untouched natural areas are confined to coastal areas and occur in a few terrestrial ecosystems, such as natural forests. The highly intensive agriculture and forestry have had a significant influence on the biodiversity and authenticity of the landscape (COM 2001, 2006, Strandberg and Krogh 2011).

The ecological frames of northwestern Europe suggest that under natural conditions and no human intervention, forests would be the dominant land cover (Bradshaw and Holmqvist 1999, Hannon et al. 2000), but the openness and exact composition remain disputed (e.g., Svenning 2002, Bradshaw et al. 2003, Nielsen et al. 2012). Pollen analyses indicate that the natural ecosystems have changed (Bradshaw and Holmqvist 1999, Hannon et al. 2000, Overballe-Petersen and Bradshaw 2011), and anthropogenic disturbances have had a decisive influence on land cover and forest composition in at least the last 3000-6000 years (Hannon et al. 2000). Hence, the potential reference for ecological restoration is a landscape deprived of any unambiguous community structure representing a natural state, with a decisively changed species composition and a strongly manipulated hydrology after millennia of human influence. Nonintervened reference systems are essentially lacking. Furthermore, most species and habitats in focus in Danish nature policy are related to seminatural landscapes (Wilhjelm-udvalget 2001).

Young (2000) suggests that conservation is a good way to stop the biodiversity decline in the short term, but that in the long run, ecological restoration will be more suitable. Therefore, we found it relevant to investigate how well the principles of ecological restoration cover the actions undertaken in Denmark. The evaluation of nature management efforts may take many points of departure. A traditional ecological evaluation would analyze the specific outcomes in terms of, e.g., ecological processes, species composition, and spatial structures in the landscape, per se. These approaches are costly and time consuming, and in many cases the outcomes may take decades to register due to the slow recovery or resilience of natural systems (Hughes et al. 2011). Alternative evaluation methods are hence needed to examine the policy behind practiced management. However, the huge variation in nature management approaches and spatial scales makes benchmarking of projects challenging.

The SER primer (SER 2004) and the "myths of restoration ecology" (Hilderbrand et al. 2005) are among the more sound and systematic approaches to formulate and define ecological restoration; hence, they are suitable for ex post and ex ante evaluation. Such evaluations are relatively rare in the scientific literature (e.g., Ruiz-Jaen and Aide 2005, Suding 2011). Based on this background, we aimed to analyze actions in Danish projects that have been cofinanced by the LIFE Nature foundation in order to reveal tendencies in the policy behind nature management. Our evaluation was based on qualitative analyses of official documents, and whenever possible, the final project reports.

\section{METHODS}

Qualitative evaluation of documents implies a number of standard assumptions, which is not usually encountered in quantitative analyses, and hence may appear odd in a natural science context. Considerations regarding the material, the data quality, the scientist as interpreter, and the need for triangulation in methodology are essential. In the following, we address this methodology.

\section{Selection criteria}

The aim of the selection criteria was to identify projects that had a significant character of ecological restoration. A large number of restoration projects have been carried out in Denmark in the past three decades. There is, however, little systematic, concise, or consistent use of terms or concepts in these projects; the project reports and evaluations arbitrarily use terms such as nature management, nature restoration, mitigation, and engineering. Hence, it was not simple to identify a sample of projects that represents processes that fulfill the criteria of ecological restoration, i.e., "the process of assisting the recovery of an ecosystem that has been degraded, damaged, or destroyed." After screening a number of projects, we decided to limit the sample to LIFE Nature projects (EC 2011a) that were finalized by October 2010 and were fully or partly executed in Denmark. Marine projects and projects with pure surveying or monitoring purposes were not included.

To gain LIFE funding, the project and the beneficiary must fulfill a range of criteria (COM 2010). Technical activity reports, including a descriptive final report, must be submitted 
Table 1. List of the 13 included projects, in chronological order.

\begin{tabular}{|c|c|c|c|c|c|}
\hline Project name & Short name & Aim & Period & LIFE number & Reference \\
\hline $\begin{array}{l}\text { Re-establishing lichen and } \\
\text { coastal heaths in the Anholt } \\
\text { desert, Denmark }\end{array}$ & Anholt & Re-establish lichen heath & 1994-1996 & $\begin{array}{l}\text { LIFE94 NAT/ } \\
\text { DK/000492 }\end{array}$ & Århus Amt (1997), EC (2011b) \\
\hline $\begin{array}{l}\text { Protection of grey dunes and } \\
\text { other habitats on Hulsig Hede/ } \\
\text { Hulsig Heath }\end{array}$ & Hulsig Heath & $\begin{array}{l}\text { Protect dune heath } \\
\text { habitats }\end{array}$ & 1996-2001 & $\begin{array}{l}\text { LIFE96 NAT/ } \\
\text { DK/003000 }\end{array}$ & $\begin{array}{l}\text { Nordjyllands Amt (2002), EC } \\
\text { (2011b) }\end{array}$ \\
\hline $\begin{array}{l}\text { The restoration of the area of } \\
\text { Vest Stadil Fjord }\end{array}$ & Vest Stadil Fjord & $\begin{array}{l}\text { Restore wetlands and } \\
\text { lakes to improve } \\
\text { conditions for prioritized } \\
\text { species }\end{array}$ & 1997-2001 & $\begin{array}{l}\text { LIFE97 NAT/ } \\
\text { DK/004199 }\end{array}$ & $\begin{array}{l}\text { Ministry of the Environment } \\
\text { (1997), Danish Forest and } \\
\text { Nature Agency (2001), EC } \\
\text { (2011b) }\end{array}$ \\
\hline $\begin{array}{l}\text { Consolidation of Bombina } \\
\text { bombina in Denmark }\end{array}$ & Bombina bombina & $\begin{array}{l}\text { Conserve the fire-bellied } \\
\text { toad (Bombina bombina) }\end{array}$ & 1999-2003 & $\begin{array}{l}\text { LIFE99 NAT/ } \\
\text { DK/006454 }\end{array}$ & Fyn County (2003) \\
\hline $\begin{array}{l}\text { Wadden Sea estuary, nature, and } \\
\text { environment improvement } \\
\text { project }\end{array}$ & Wadden Sea & $\begin{array}{l}\text { Restore natural hydrology } \\
\text { and change agricultural } \\
\text { practices }\end{array}$ & 1999-2002 & $\begin{array}{l}\text { LIFE99 NAT/ } \\
\text { DK/006456 }\end{array}$ & $\begin{array}{l}\text { Ministry of the Environment } \\
\text { and Energy (1999), Danish } \\
\text { Forest and Nature Agency } \\
(2003)\end{array}$ \\
\hline $\begin{array}{l}\text { Restoration of habitats and } \\
\text { wildlife of the Skjern River }\end{array}$ & Skjern River & $\begin{array}{l}\text { Improve conditions for } \\
\text { wetland fauna, restore } \\
\text { self-purification of the } \\
\text { river, and improve the } \\
\text { recreational value }\end{array}$ & 2000-2004 & $\begin{array}{l}\text { LIFE00 NAT/ } \\
\text { DK/007116 }\end{array}$ & $\begin{array}{l}\text { Ministry of the Environment } \\
\text { and Energy (2000), Oxboel } \\
\text { State Forest District (2005) }\end{array}$ \\
\hline $\begin{array}{l}\text { Restoration of dune habitats } \\
\text { along the Danish West Coast }\end{array}$ & Dune Habitats & $\begin{array}{l}\text { Regain a favorable } \\
\text { conservation status for } \\
\text { the Danish dune habitats }\end{array}$ & $2002-2005$ & $\begin{array}{l}\text { LIFE02 NAT/ } \\
\text { DK/008584 }\end{array}$ & $\begin{array}{l}\text { Ministry of the Environment } \\
\text { (2002), Danish Forest and } \\
\text { Nature Agency (2005) }\end{array}$ \\
\hline $\begin{array}{l}\text { Improving status of coastal } \\
\text { lagoon Tryggelev Nor, Denmark- } \\
\text { IMAGE }\end{array}$ & Tryggelev Nor & $\begin{array}{l}\text { Obtain a favourable } \\
\text { conservation status of the } \\
\text { coastal lagoon }\end{array}$ & 2002-2006 & $\begin{array}{l}\text { LIFE2002 NAT/ } \\
\text { DK/8588 }\end{array}$ & Fyn County $(2002,2006)$ \\
\hline $\begin{array}{l}\text { Restoration of Lake Fure-a } \\
\text { nutrient-rich lake near } \\
\text { Copenhagen }\end{array}$ & Lake Fure & $\begin{array}{l}\text { Obtain clear water and } \\
\text { improve conditions for } \\
\text { flora and fauna }\end{array}$ & 2002-2006 & $\begin{array}{l}\text { LIFE02NAT/ } \\
\text { DK/8589 }\end{array}$ & Frederiksborg County (2006) \\
\hline $\begin{array}{l}\text { RODGID-Restoration of Dry } \\
\text { Grasslands in Denmark }\end{array}$ & Dry Grasslands & $\begin{array}{l}\text { Achieve a favourable } \\
\text { conservation status for } \\
\text { three priority dry } \\
\text { grasslands habitat types }\end{array}$ & 2004-2008 & $\begin{array}{l}\text { LIFE04NAT/ } \\
\text { DK/000020 }\end{array}$ & $\begin{array}{l}\text { Ministry of the Environment } \\
(2004,2008)\end{array}$ \\
\hline $\begin{array}{l}\text { BALTRIT_Protection of } \\
\text { Triturus cristatus in Eastern } \\
\text { Baltic Region }\end{array}$ & Triturus cristatus & $\begin{array}{l}\text { Conserve isolated } \\
\text { population and restore } \\
\text { metapopulation structure } \\
\text { of Triturus cristatus }\end{array}$ & 2004-2008 & $\begin{array}{l}\text { LIFE04 NAT/ } \\
\text { EE/000070 }\end{array}$ & $\begin{array}{l}\text { Ministry of the Environment of } \\
\text { the Republic of Estonia (2009) }\end{array}$ \\
\hline $\begin{array}{l}\text { ASPEA-Action for sustaining } \\
\text { the population of Euphydryas } \\
\text { aurinia }\end{array}$ & Euphydryas aurinia & $\begin{array}{l}\text { Bring the isolated } \\
\text { population of Euphydryas } \\
\text { aurinia into favorable } \\
\text { conservation status }\end{array}$ & $2005-2008$ & $\begin{array}{l}\text { LIFE05 NAT/ } \\
\text { DK/000151 }\end{array}$ & $\begin{array}{l}\text { Danish Forest and Nature } \\
\text { Agency (2009) }\end{array}$ \\
\hline $\begin{array}{l}\text { Restoration of Meadow Bird } \\
\text { Habitats-REMAB }\end{array}$ & Meadow Birds & $\begin{array}{l}\text { Restore and maintain a } \\
\text { favorable conservation } \\
\text { status for two wading bird } \\
\text { species and associated } \\
\text { habitat types }\end{array}$ & 2006-2009 & $\begin{array}{l}\text { LIFE06 NAT/ } \\
\text { DK/000158 }\end{array}$ & $\begin{array}{l}\text { Danish Forest and Nature } \\
\text { Agency (2010) }\end{array}$ \\
\hline
\end{tabular}

to the Commission within three months of the end of the project (COM 2010). If possible, we based our analyses on final reports, but in a few cases the final report was inaccessible; therefore, the application form and other official descriptive documents were used (Table 1). Due to the lack of descriptive documents, the project Management of North European Heathland Areas in Relation to the Directive 79/409/EEC (LIFE92 NAT/DK/013600) was omitted. Another project, Restoration Forest-Restoration of Large Areas of Natural Forest for the Benefit of Endangered Birds, Plants, and
Biotopes (LIFE95 NAT/DK/00216), had the character more of a government policy than an active restoration project, so was also omitted. Of 22 LIFE Nature-supported projects initiated in Denmark, only 13 projects had fulfilled our criteria by October 2010. The spatial distribution of those projects is shown in Fig. 1.

\section{Document analyses}

The documents included in the analyses comprised mainly project applications and final reports for projects in which 
Fig. 1. Sites included in the analyses. Projects are identified by numbers, following the same chronology used in Table 1. (1) Anholt, one site; (2) Hulsig Heath, one site; (3) Vest Stadil Fjord, one site; (4) Bombina bombina, seven sites; (5) Wadden Sea, one site; (6) Skjern River, one site; (7) Dune Habitats, 12 sites; (8) Tryggelev Nor, one site; (9) Lake Fure, one site; (10) Dry Grasslands, 11 sites; (11) Triturus cristatus, two sites; (12) Euphydryas aurinia, five sites; (13) Meadow Birds, four sites. Sites outside Denmark in the Triturus cristatus project are not included.

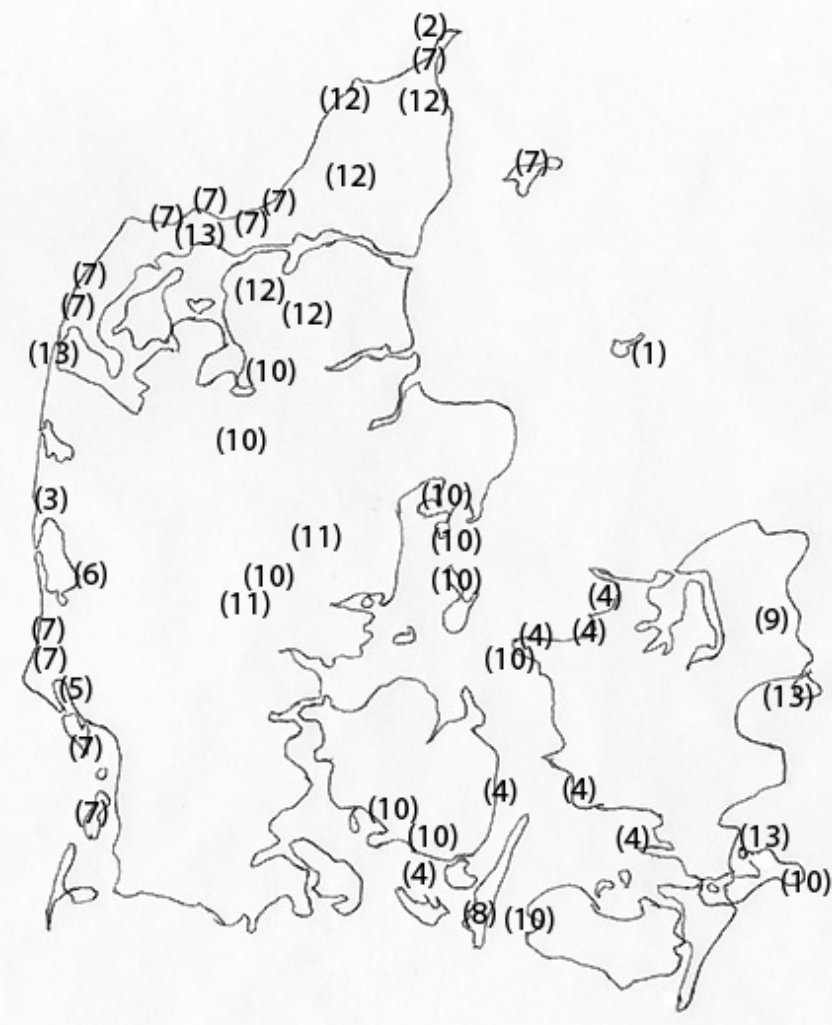

some kind of nature management activity that fit the general definition of ecological restoration took place. That is, the exact term "ecological restoration" or its Danish equivalent was not necessarily explicitly mentioned in the project description or final report. The reports are official documents that are used as communication tools between local authorities and the EU LIFE authorities. The reports have institutional authorship, that is, though a specific author may be identified, he or she acts on behalf of a public institution. But even authors of official documents may be reflective and conscious of reputation. According to Dahler-Larsen (2005), the author may attempt to fix a certain definition of reality given certain circumstances. The documents aim at one major goal: to fulfill criteria and obligations set by the funding authority. Therefore, the documents are not meant to fulfill any other criteria, which we kept in mind when evaluating them by using the SER criteria as a benchmark.

The documents were analyzed to judge whether and how well the principles of ecological restoration covered the actions conducted as part of the projects. The methodology used is what Canter and Alison (2003) refer to as unobtrusive: there is no contact with the author, no impact on the creation of the document, and no reactivity (i.e., no impact on the study object). The reports were analyzed using a standardized interpretation guide (Appendix 1). Concepts and terms were interpreted using the terminology presented in the SER primer (SER 2004).

First, we analyzed the fulfillment of the nine attributes from the SER primer (SER 2004) by reviewing the official project descriptions. For each project, we questioned primarily whether the intentions of the attributes were taken into consideration (C) or not (NC).

Second, we evaluated how well the project had fulfilled the given attribute, i.e., whether the project did or had what was required by the attribute, no matter the answer to the first question. This was done by searching for relevant descriptions as part of the standardized interpretation guide (Appendix 1). We differentiated whether the attribute was fulfilled (F), partly fulfilled (PF), or not met (NM). In some cases, the official project description did not have sufficient information to clarify the degree of fulfillment (-). This could be either because the project did not consider the attribute or because the reports were written before it was possible to draw any conclusion.

Third, we analyzed the perception behind the projects by comparing tendencies in the official descriptions with the myths of restoration ecology (Hilderbrand et al. 2005). This was based on five questions, one assigned for each myth (Text box 1).

In order to perform a triangulation analysis (Dahler-Larsen 2005), two researchers independently scrutinized the projects before comparing the results with each other. This method should reveal systematic differences in the personal evaluations and allow corrections to be made in the evaluations.

\section{Box 1:}

The five questions used to identify the presence of each myth of restoration ecology, based on Hilderbrand et al. (2005), were:

The myth of the Carbon Copy

- Is there a single-state endpoint described as the goal of the project, i.e., defined community assembly, without recognizing the uncertainties related to future changes? 
The myth of the Field of Dreams

- Does the project focus solely on physico-chemical conditions, based on a self-organization approach, without addressing the uncertainties related to outcome?

The myth of Fast-Forwarding

- Does the project aim at accelerating ecosystem development pathways without recognizing slow recovering, time-dependent ecological processes?

The myth of the Cookbook

- Is the project based on methods adopted from other projects, without consideration/incorporation of sitespecific conditions (idiosyncrasies)?

The myth of Command and Control and the Sisyphus Complex

- Does the project aim at actively controlling ecosystem structure and function to manage for a particular ecosystem state indefinitely into the future, without recognizing uncertainties arising from changes in dominant large-scale drivers?

\section{RESULTS}

Based on the aims of each project, we classified them into three main categories (Table 2): (1) projects aimed at conservation of a single species or a group of species, (2) projects aimed at restoration of set-aside areas, mainly on abandoned agricultural land, and (3) projects aimed at habitat management of Natura 2000 areas. The number of projects grouped into each of the three categories was equally abundant, and we did not investigate intercategorical differences.

No project considered or fulfilled all nine attributes (Table 2). Most projects (10 of the 13) used reference sites for defining diversity and community structure goals (attribute 1). An example of reference information was the use of historical records. Eleven of the 13 projects fulfilled the reference criteria (attribute 1), for instance, revealed by a botanical survey based on the Raunkiær method. Four of the 13 projects considered whether nonindigenous species were present (attribute 2). All projects that considered the presence of nonindigenous species also fulfilled this attribute, at least partly. In the Vest Stadil Fjord project, which aimed to restore former lagoon wetlands on land reclaimed for farming, a botanical survey showed the presence of the nonindigenous and strongly invasive Rosa rugosa, but presumably no actions were taken to combat this species. Three of the 13 projects considered the presence of functional groups (attribute 3), whereas four of the 13 seemed to fulfill this attribute, at least to some degree. An example is the project Tryggelev Nor, where higher biodiversity of aquatic plants and animals, as well as improved food web structures constituted the complied goals. However, for several of the projects, this attribute was difficult to evaluate.

All analyzed projects considered restoring an appropriate physical environment (attribute 4). Only the project Lake Fure did not fulfill this attribute. It aimed to improve ecological conditions of the lake as a whole, as well as for waterfowl and elodeid plants, but a high internal phosphorus load was not sufficiently lowered by the end of the project. Eight of the 13 projects considered restoring normal functioning ecosystems (attribute 5), and six succeeded in fulfilling this attribute. An example of fulfillment is the river restoration in Skjern River, where sedimentation and turf buildup processes became restored.

Almost all the projects considered the landscape dimension (attribute 6), and all projects seemed to fulfill it. The projects Meadow Birds, Vest Stadil Fjord, Skjern River, and Wadden Sea were all wetland restoration projects with a shared focus on wetland birds. They were adjacent to one another and were located on the important route for migrating birds, known as the West Palearctic Flyway, and were an example of integration into a larger ecological matrix. The presence of external threats was considered in 10 of the 13 projects, and was evaluated to be eliminated in four projects (attribute 7). A prevalent problem in most project areas was nitrogen deposition due mainly to high stocking densities of domestic animals and widespread use of sludge in the surrounding areas.

Resilience of the restored ecosystem was considered in six of the 13 projects (attribute 8). Since resilience is a timedependent phenomenon, it was difficult to evaluate the fulfillment of this attribute. In the two large projects that were aimed at restoring natural dune heaths, i.e., Dune Habitats and Hulsig Heath, large surveys of the ability of the natural vegetation to re-establish showed good recovery, and both projects were assessed as having fulfilled the attribute to some degree. Eight of the 13 projects considered the selfsustainability and future development of the restored ecosystems (attribute 9). Five of the 13 projects did not meet the intention of the attribute, either because the idea of ecosystem development contradicted the aims, e.g., in the project Dry Grassland, aimed at increasing the area of grassland habitats that was formerly overgrown, or in the project Lake Fure, where the restored lake ecosystem was not yet self-sustaining but was dependent on an artificial oxygen supply. In the projects Hulsig Heath and Anholt, natural vegetative development was allowed, and the projects were evaluated as having partly fulfilled the attribute. Similarly, the allowed dynamic stream development in Skjern River was partly fulfillment.

Two of the myths described by Hilderbrand et al. (2005) were remarkably common among the 13 projects (Table 3 ). The myth of the Carbon Copy was recognized in 12 projects, and 


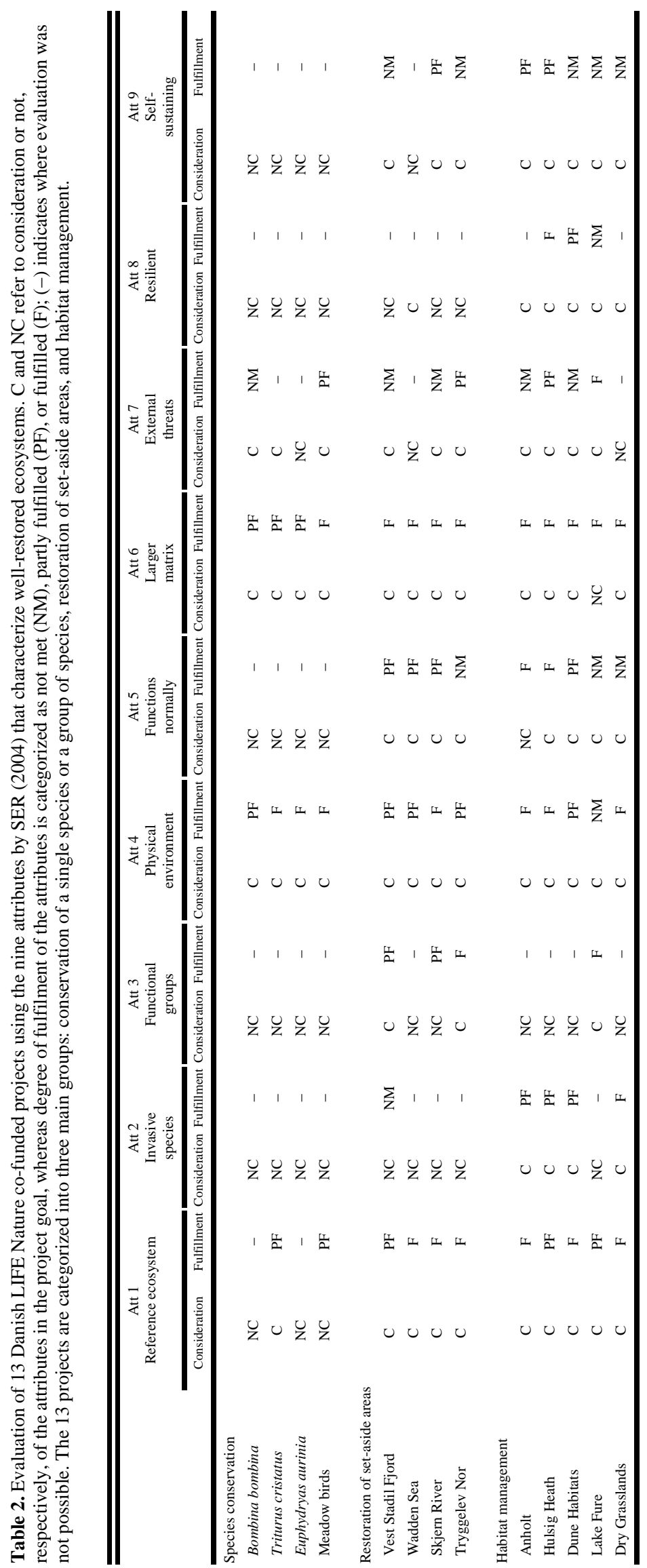


the myth of Command and Control was recognized in 11 of the 13 projects. All projects had predefined target species and/ or habitat types, and most did not include acceptance of future changes in species composition or distribution as expressed by the myth of Carbon Copy. To preserve the appearance and species assembly of the restored habitat, most projects included recurring management that expressed the myth of Command and Control. Control of vegetation development, e.g., by controlled grazing and ongoing mechanical removal of colonizing trees, was especially prevalent.

On the contrary, the myth of the Cookbook was not recognized in any of the projects because they all had involved preliminary site studies or used historical reference conditions. Only the Bombina bombina project aimed to accelerate ecosystem development, i.e., the myth of Fast-Forwarding, which was articulated in the strong focus on a captive breeding program. The myth of the Field of Dreams was recognized in less than half of the projects (five of the 13), which expressed a sole focus on physico-chemical conditions without addressing that the outcome might hence be uncertain.

\section{DISCUSSION}

The main result of our analyses is that no project was found to consider or fulfill all the nine attributes of the SER primer on ecological restoration (SER 2004), and the projects were frequently based on at least two well-defined myths in restoration ecology (Hilderbrand et al. 2005). However, two important questions concerning the data and the methods must be addressed.

The analyses comprised a limited number of the projects that were financially supported by the LIFE Nature program and were carried out in Denmark during the last decades. However, these projects presumably made up a representative sample of projects that fulfilled the selection criteria described in the Methods: Selection criteria. Furthermore, there is reason to believe that most large-scale projects in Denmark have received this kind of financial support, and hence were included here. Beneficiaries included the governmental Forest and Nature Agency and municipalities but also private foundations. Some of the projects did not include the term "restoration" in their title, but this was not a selection criterion since this would require that the project managers had made equal semantic decisions during the 18 years covered. On the contrary, the LIFE Nature-supported projects are contributing to the implementation of the Habitats Directive (Council Directive 92/43/EEC), which seeks to not only maintain but also restore natural habitats and species at favorable conservation statuses (EC 2003).

The included reports were intended mainly to document the expenditures as a correspondence between the beneficiary and the contributor. Furthermore, there was no prescribed composition for a final report; hence, the content varied and was not always of traditional scientific standard. The use of a standardized interpretation guide compensated for a possible two-sided source of error: the documents varied because they were written by different authors at different times, and a researcher in qualitative analyses inevitably has preoccupations due to human perception. Both problems were addressed by using the standardized interpretation guide (Appendix 1) and questions (Text box 1), and by conducting cross-checking by two researchers.

This study was built on an interpretation of the SER primer, where ecological restoration involves actions that initiate a process that induces unpredictable development along a trajectory and with no further requirement of external assistance (SER 2004). This interpretation may gain growing support because it appears that restoration ecology cannot turn back the clock (Hobbs and Cramer 2008, Suding 2011), and future challenges, like the spread of nonindigenous species and changing climatic conditions, seem to restrict success when certain ecological states are the goal (Harris et al. 2006, Hobbs and Cramer 2008, Suding 2011). Other interpretations are possible, which reveals an ambiguity in the SER primer (SER 2004) when it comes to the restoration of seminatural areas in millennia-old cultural landscapes, and the incorporation of recurring management that simulates traditional land uses. By using the standardized interpretation guide, all projects were evaluated based on the same interpretation of ecological restoration, i.e., with no regard to the standards at the time of the project initiation. Hence, the results cannot and are not intended to be used to disqualify the projects, but to reveal tendencies in Danish nature policy in comparison with this specific interpretation of ecological restoration.

Following the SER primer (SER 2004) and the adapted interpretation of ecological restoration, we found that no project considered or fulfilled all nine attributes. The project that was best covered by the principles of ecological restoration was Hulsig Heath, where no myths were identified and which lacked only consideration and fulfillment of the presence of all functional groups. In general, we found that some attributes were more often considered and fulfilled than others. They seem to have in common an association with fundamental requirements for the existence of the target species or habitats. An appropriate physical environment (attribute 4) and connectivity with adjacent sites (attribute 6) are examples of such. The use of reference sites (attribute 1) and the elimination of external threats (attribute 7) could also support the favorable conservation status of target species or habitats, and likewise, they were frequently found to be considered in our analysis. Other attributes were associated more with the continuity of the ecosystem as a whole. The two attributes that were most infrequently fulfilled deal with the resilience (attribute 8) and self-sustainability (attribute 9) of the restored systems. Only two of the analyzed projects 
Table 3. Evaluation of the 13 analyzed projects by use of the five myths of restoration ecology by Hilderbrand et al. (2005). Presence of the myths is indicated with (+), whereas (-) indicates that the myths have not been recognized.

\begin{tabular}{|c|c|c|c|c|c|}
\hline & Carbon Copy & Field of Dreams & Fast-Forwarding & Cook-book & $\begin{array}{c}\text { Command } \\
\text { and Control }\end{array}$ \\
\hline \multicolumn{6}{|l|}{ Species conservation } \\
\hline Bombina bombina & + & - & + & - & + \\
\hline Triturus cristatus & + & + & - & - & + \\
\hline Euphydryas aurinia & + & + & - & - & + \\
\hline Meadow birds & + & + & - & - & + \\
\hline \multicolumn{6}{|c|}{ Restoration of set-aside areas } \\
\hline Vest Stadil Fjord & + & - & - & - & + \\
\hline Wadden Sea & + & - & - & - & + \\
\hline Skjern River & + & + & - & - & + \\
\hline Tryggelev Nor & + & + & - & - & + \\
\hline \multicolumn{6}{|l|}{ Habitat management } \\
\hline Anholt & + & - & - & - & - \\
\hline Hulsig Heath & - & - & - & - & - \\
\hline Dune Habitats & + & - & - & - & + \\
\hline Lake Fure & + & - & - & - & + \\
\hline Dry Grasslands & + & - & - & - & + \\
\hline
\end{tabular}

accepted, to some degree, a future development along an open trajectory.

Our findings are parallel to those of Ruiz-Jean and Aide (2005), who found that ecological processes were the least evaluated attribute of restored ecosystems. We tried to explain this trend by using the myths of restoration ecology (Hilderbrand et al. 2005). According to the authors, the presence of myths is not necessarily flawed but rather an expression of a simplification of ecological complexities. Project authorities should therefore be aware of the possible consequences. We found that the two assumptions that there is a predictable single endpoint (the myth of the Carbon Copy) and that nature is controllable (the myth of Command and Control) were notably frequent in the Danish projects. The incorporation of recurring management, like grazing or prescribed heathland burning, was especially prevalent in the analyzed projects. Even though we evaluated this as a possible expression of the Command and Control approach to restoration, it can be argued to be a positive feature as well. In COWI's (2009a) evaluation of the LIFE program in Denmark, this incorporation of future management leads to an assessment that the project has high sustainability. Hobbs and Cramer (2008) discuss this opposing approach in ecological restoration, and argue that even though there is a common assumption that restoration aims to fix problems and then move on, so-called one-off interventions, there is often a need for ongoing management. Basically, such a need depends on the goals behind the individual project, and therefore reflects the perception and the policy behind nature management. In the 13 projects analyzed in this study, most recurring management aimed to maintain ecosystems at a certain state, associated with the desired landscapes similar to those of traditional land uses. In two projects, the recurring management was target driven and aimed at combating nonnative invasive species.

According to an evaluation of the whole LIFE Nature program (COWI 2009b), the objective is to contribute to the implementation of the Council Directive 79/409/EEC (Birds Directive) and Council Directive 92/43/EEC (Habitats Directive). Having this in mind, the objectives of the analyzed projects are to improve favorable conservation statuses of Annex birds, habitats, and species. A recent review by Halada et al. (2011) identified habitats of European importance that depend on, or can benefit from, agricultural practices, mainly grazing and mowing. The authors found 63 of such habitat types to be covered by the Birds and Habitats Directives, of which several were the target of the projects analyzed in this study. Hence, the incorporation of grazing and ongoing mechanical removal of trees that are colonizing open habitats in Danish LIFE Nature projects is indeed assisting the overall objectives, and is needed. However, in these analyses, we found that even under this overall objective, it is possible to make nature management projects that are close to the principles of ecological restoration, as in Hulsig Heath. Our analyses reveal a general approach to nature as controllable and with predictable development, described as the myth of Command and Control and the myth of the Carbon Copy. Further, our results reveal that the focus in Danish LIFE Nature 
projects has been on structures, i.e., species and appearance, rather than on ecological processes, i.e., resilience and natural dynamics with inherent unpredictable development. This clearly indicates that nature policy in Denmark is based largely on a control paradigm, which, however, is in line with more than 6000 years tradition of agriculture and intensive land use, leading to a high population density and absence of nonmanaged nature.

The lack of focus on ecological processes in the analyzed projects in this study is also in line with evaluations of other branches of environment policies. When evaluating the agrienvironmental policies of the European Union's Common Agricultural Policy, Primdahl et al. (2003) found that the focus was on performance effects, typically the number of farmers that were adopting a certain management practice, or the area under a particular management practice, rather than outcome effects, e.g., presence of species or reduction of pollution. Likewise, within ecological restoration, specific outcomes may take decades to reach, and policies may be regarded as a failure if the expected outcomes are not accomplished despite the fact that the actors behaved as suggested, e.g., if farmers adopted a certain practice. When the official documents from the LIFE Nature projects focus on performance effects in the same way, it is partly because they are intended to report obligations set by the funding authorities, in this case, the European Union.

A complete evaluation should include analyses of concrete outcomes on the landscape, per se. However, the results of this study reveal tendencies in the nature policy in Denmark and in the European Union LIFE Nature program to focus on structures rather than processes. Due to the time scale of ecosystem development and the unpredictability of the future, it is impossible to evaluate the long-term success of these projects.

According to the SER primer (SER 2004) "restoration initiates ecosystem development along a preferred trajectory, and thereafter allows autogenic processes to guide subsequent development with little or no human interference" and acceptance of unpredictable development, whereas "ecological engineering involves manipulation of natural materials, living organisms and the physical-chemical environment to achieve specific human goals and solve technical problems." Our results indicate that a control paradigm and a goal of predictive end points have been pronounced in Danish nature policy, whereas it is maybe better referred to as ecological engineering or something else (SER 2004). It is our opinion that the interpretation of ecological restoration in the present analyses is neither inappropriate nor impossible in the intensively cultivated northwestern Europe. The 100-year vision of the Wicken Fen in the UK (Hughes et al. 2011) is an example of a restoration project that has adopted the open-ended approach. It follows by the results of this study that the definition and interpretation of ecological restoration is ambiguous, and according to land use history, there is a need for concepts and approaches to be clearly defined.

Responses to this article can be read online at: http://www.ecologyandsociety.org/issues/responses. $\mathrm{php} / 5847$

\section{Acknowledgments:}

This study was cofunded by the Nordic Council of Ministers and was conducted as part of the project ReNo-Restoration of Damaged Ecosystems in the Nordic Countries-a Nordic multidisciplinary network. We are thankful to the two anonymous reviewers who provided useful feedback which improved this article.

\section{LITERATURE CITED}

Århus Amt. 1997. Naturpleje i Anholtørkenen. Afsluttende rapport. Marts 1997. Århus Amt, Natur og Miljø, Denmark.

Bradshaw, R. H. W., G. E. Hannon, and A. M. Lister. 2003. A long-term perspective on ungulate-vegetation interactions. Forest Ecology and Management 181:267-280. http://dx.doi. org/10.1016/S0378-1127(03)00138-5

Bradshaw, R., and B. H. Holmqvist. 1999. Danish forest development during the last 3000 years reconstructed from regional pollen data. Ecography 22:53-62. http://dx.doi. org/10.1111/j.1600-0587.1999.tb00454.x

Canter, D., and A. L. Alison. 2003. Converting evidence into data: the use of law enforcement archives as unobtrusive measurement. Qualitative Report 8:151-176. [online] URL: http://www.nova.edu/ssss/QR/QR8-2/canter.pdf

Commission of the European Communities (COM). 2001. Communication from the Commission to the Council and the European parliament-biodiversity action plan for agriculture. [online] URL: http://ec.europa.eu/agriculture/ envir/biodiv/162_en.pdf

Commission of the European Communities (COM). 2006. Communication from the Commission. Halting the loss of biodiversity by 2010 - and beyond. Sustaining ecosystem services for human well-being. [online] URL: http://eur-lex. europa.eu/LexUriServ/LexUriServ.do?uri=COM:2006:0216: FIN:EN:PDF

Commission of the European Communities (COM). 2010. Common provisions. [online] URL: http://ec.europa.eu/ environment/life/toolkit/pmtools/lifeplus/documents/ commonprov_10_en.pdf 
COWI. 2009a. Ex-post evaluation of projects and activities financed under the LIFE Programme. Country-by-country analysis. Denmark. [online] URL: http://ec.europa.eu/ environment/life/publications/lifepublications/evaluation/documents/ eval denmark.pdf

COWI. 2009b. Ex-post evaluation of projects and activities financed under the LIFE Programme. Final report. Part 4: thematic analysis—nature. [online] URL: http://ec.europa.eu/ environment/life/publications/lifepublications/evaluation/documents/ lifeval_nature.pdf

Dahler-Larsen, P. 2005. Dokumenter som objektiveret social virkelighed. Pages 235-254 in M. Järvinen and N. Mik-Meuer, editors. Kvalitative metoder $i$ et interaktionistisk perspektiv. Hans Reitzels Forlag, Copenhagen, Denmark.

Danish Forest and Nature Agency. 2001. Vest Stadil Fjord. LIFE-Nature final report. Ministry of the Environment, Danish Forest and Nature Agency, COWI, Ringkøbing County and NERI, Denmark.

Danish Forest and Nature Agency. 2003. Waddensea estuary nature and environment improvement project (WEP). LIFENature final report. Ministry of the Environment and Energy, Danish Forest and Nature Agency, Denmark.

Danish Forest and Nature Agency. 2005. Dune habitats: final technical report. Ministry of the Environment and Energy, Danish Forest and Nature Agency, Denmark.

Danish Forest and Nature Agency. 2009. Final report: ASPEA - action for sustaining the population of Euphydryas aurinia. Danish Forest and Nature Agency, Denmark.

Danish Forest and Nature Agency. 2010. Technical interim: REMAB - restoration of meadow bird habitats. Danish Forest and Nature Agency, Denmark.

Davis, M. A., and L. B. Slobodkin. 2004. The science and values of restoration ecology. Restoration Ecology 12:1-3. http://dx.doi.org/10.1111/j.1061-2971.2004.0351.x

European Commission (EC). 2003. LIFE FOCUS: LIFE for Natura 2000: 10 years implementing the regulation. European Commission, Environment Directorate-General, LIFE Unit, Belgium. [online] URL: http://ec.europa.eu/environment/life/ publications/lifepublications/lifefocus/documents/lifefornatura en. pdf

European Commission (EC). 2011a. LIFE Programme, European Commission, Environment Directorate-General, Belgium. [online] URL: http://ec.europa.eu/environment/ life/

European Commission (EC). 2011b. Project database with fact sheets on LIFE projects. European Commission, Environment Directorate-General, Belgium. [online] URL: http://ec. europa.eu/environment/life/project/Projects/index.cfm
Eurostat. 2011. Agriculture and fishery statistics-main results-2009-10. [online] URL: http://epp.eurostat.ec. europa.eu/cache/ITY OFFPUB/KS-FK-11-001/EN/KS-FK-11-001EN.PDF

Fyn County. 2002. Application form for the project improving status of the coastal lagoon Tryggelev Nor, DenmarkIMAGE. Fyn County, Denmark.

Fyn County. 2003. Final report part II, project conclusions. Fyn County, Denmark

Fyn County. 2006. Improving status of the coastal lagoon Tryggelev Nor, Denmark-IMAGE: final report, September 2006. Fyn County, Denmark.

Frederiksborg County. 2006. Final report. Restoration of Lake Fure-a nutrient-rich lake near Copenhagen. Frederiksborg County, Denmark.

Halada, L., S. Evans, C. Romão, and J-E. Petersen. 2011. Which habitats of European importance depend on agricultural practices? Biodiversity and Conservation 20:2365-2378. http://dx.doi.org/10.1007/s10531-011-9989$\mathrm{Z}$

Hannon, G. E., R. Bradshaw, and J. Emborg. 2000. 6000 years of forest dynamics in Suserup Skov, a seminatural Danish woodland. Global Ecology \& Biography 9:101-114. http://dx. doi.org/10.1046/j.1365-2699.2000.00145.x

Harris, J. A., R. J. Hobbs, E. Higgs, and J. Aronson. 2006. Ecological restoration and global climate change. Restoration Ecology 14(2):170-176. http://dx.doi.org/10.1111/ j.1526-100X.2006.00136.X

Hilderbrand, R. H., A. C. Watts, and A. M. Randle. 2005. The myths of restoration ecology. Ecology and Society 10:19. [online] URL: http://www.ecologyandsociety.org/vol10/iss1/ $\underline{\operatorname{art} 19 /}$

Hobbs, R. J. 2007. Setting effective and realistic restoration goals: key directions for research. Restoration Ecology 15:354-357. http://dx.doi.org/10.1111/j.1526-100X.2007.00225. $\underline{\mathrm{X}}$

Hobbs, R. J., and V. A. Cramer. 2008. Restoration ecology: interventionist approaches for restoring and maintaining ecosystem function in the face of rapid environmental change. Annual Review of Environment and Resources 33:39-61. http://dx.doi.org/10.1146/annurev.environ.33.020107.113631

Hughes, F. M. R., P. A. Stroh, W. M. Adams, K. J. Kirkby, J. O. Mountford, and S. Warrington. 2011. Monitoring and evaluating large-scale, 'open-ended' habitat creation projects: a journey rather than a destination. Journal for Nature Conservation 19:245-253. http://dx.doi.org/10.1016/j.jnc.2011.02.003

Madsen, L. M. 2003. New woodlands in Denmark: the role of private landowners. Urban Forestry \& Urban Greening 
1:185-195. http://dx.doi.org/10.1078/1618-8667-00018 http:// dx.doi.org/10.1078/1618-8667-00018

Ministry of the Environment. 1997. The restoration of the area of Vest Stadil Fjord. Application form. Ministry of the Environment, Forest and Nature Agency, Denmark.

Ministry of the Environment. 2002. Restoration of dune habitats along the Danish west coast. Application form. Ministry of the Environment, The Danish Forest and Nature Agency, Denmark.

Ministry of the Environment. 2004. Application form: restoration of dry grasslands in Denmark-RODGID. Ministry of the Environment, The Danish Forest and Nature Agency, Denmark.

Ministry of the Environment. 2008. Technical final report: restoration of dry grasslands in Denmark-RODGID. Ministry of the Environment, The Danish Forest and Nature Agency, Denmark.

Ministry of the Environment and Energy. 1999. LIFE application. Waddensea estuary, nature and environment improvement. Ministry of the Environment and Energy, National Forest and Nature Agency, Denmark.

Ministry of the Environment and Energy. 2000. Restoration of habitats and wildlife of the Skjern River. Application form. Ministry of the Environment and Energy, The National Forest and Nature Agency, Denmark.

Ministry of the Environment of the Republic of Estonia. 2009. Final report: protection of Triturus cristatus in Eastern Baltic region. The Ministry of the Environment of the Republic of Estonia, Estonia.

Nielsen, A. B., T. Giesecke, M. Theuerkauf, I. Feeser, K. E. Behre, H. J. Beug, S. H. Chen, J. Christiansen, W. Dorfler, E. Endtmann, S. Jahns, P. de Klerk, N. Kuhl, M. Latalowa, B. V. Odgaard, P. Rasmussen, J. R. Stockholm, R. Voigt, J. Wiethold, and S. Wolters. 2012. Quantitative reconstructions of changes in regional openness in north-central Europe reveal new insights into old questions. Quaternary Science Reviews 47:131-149. http://dx.doi.org/10.1016/j.quascirev.2012.05.011

Nordjyllands Amt. 2002. Nature conservation on Hulsig Hede. LIFE-Nature final report. June 2002. Nordjyllands Statsskovdistrikt and Nordjyllands Amt, Natur- og Miljøkontoret, Denmark.

Overballe-Petersen, M. V., and R. H. W. Bradshaw. 2011. The selection of small forest hollows for pollen analysis in boreal and temperate forest regions. Palynology 35:146-153. http:// dx.doi.org/10.1080/01916122.2011.558173

Oxboel State Forest District. 2005. Restoration of habitats and wildlife of the Skjern River. Final report. Ministry of the Environment, Danish Forest and Nature Agency, Oxboel State Forest District, Denmark.
Pedersen, A. B. 2010. The fight over Danish nature: explaining policy network change and policy change. Public Administration 88:346-363. http://dx.doi.org/10.1111/ j.1467-9299.2009.01790.x

Pedersen, M. L., J. M. Andersen, K. Nielsen, and M. Linnemann. 2007. Restoration of Skjern River and its valley: project description and general ecological changes in the project area. Ecological Engineering 30:131-144. http://dx. doi.org/10.1016/j.ecoleng.2006.06.009

Primdahl, J., B. Peco, J. Schramek, E. Andersen, and J. J. Oñate. 2003. Environmental effects of agri-environmental schemes in Western Europe. Journal of Environmental Management 67:129-138. http://dx.doi.org/10.1016/S0301-4797 (02)00192-5

Ruiz-Jean, M. C., and T. M. Aide. 2005. Restoration success: how is it being measured? Restoration Ecology 13:569-577. http://dx.doi.org/10.1111/j.1526-100X.2005.00072.x

Society for Ecological Restoration International Science \& Policy Working Group (SER). 2004. SER international primer on ecological restoration. [online] URL: http://www.ser.org/ resources/resources-detail-view/ser-international-primer-onecological-restoration

Strandberg, B., and P. H. Krogh. 2011. Agerland. Pages 97104 in R. Ejrnæs, P. Wiberg-Larsen, T. E. Holm, A. Josefson, B. Strandberg, B. Nygaard, L. W. Andersen, A. Winding, M. Termansen, M. D. D. Hansen, M. Søndergaard, A. S. Hansen, S. Lundsteen, A. Baattrup-Pedersen, E. Kristensen, P. H. Krogh, V. Simonsen, B. Hasler, and G. Levin. 2011. Danmarks biodiversitet 2010-status, udvikling og trusler. National Environmental Research Institute, Aarhus University. NERI Technical Report No. 815. [online] URL: http://www2.dmu. dk/pub/fr815.pdf

Suding, K. N. 2011. Toward an era of restoration in ecology: successes, failures, and opportunities ahead. Annual Review of Ecology, Evolution, and Systematics 42:465-487. http://dx. doi.org/10.1146/annurev-ecolsys-102710-145115

Svenning, J. C. 2002. A review of natural vegetation openness in north-western Europe. Biological Conservation 104:133148. http://dx.doi.org/10.1016/S0006-3207(01)00162-8

Wilhjelm-udvalget. 2001. En rig natur i et rigt samfund. Skovog Naturstyrelsen, Denmark. [online] URL: http://www.sns. dk/udgivelser/2002/87-7279-378-3/pdf/helepubl.pdf

Winterhalder, K., A. F. Clewell, and J. Aronson. 2004. Values and science in ecological restoration - a response to Davis and Slobodkin. Restoration Ecology 12:4-7. http://dx.doi. org/10.1111/j.1061-2971.2004.12001.X

Young, T. P. 2000. Restoration ecology and conservation biology. Biological Conservation 92:73-83. http://dx.doi. org/10.1016/S0006-3207(99)00057-9 


\section{Appendix 1. Standardized interpretation guide}

General project information

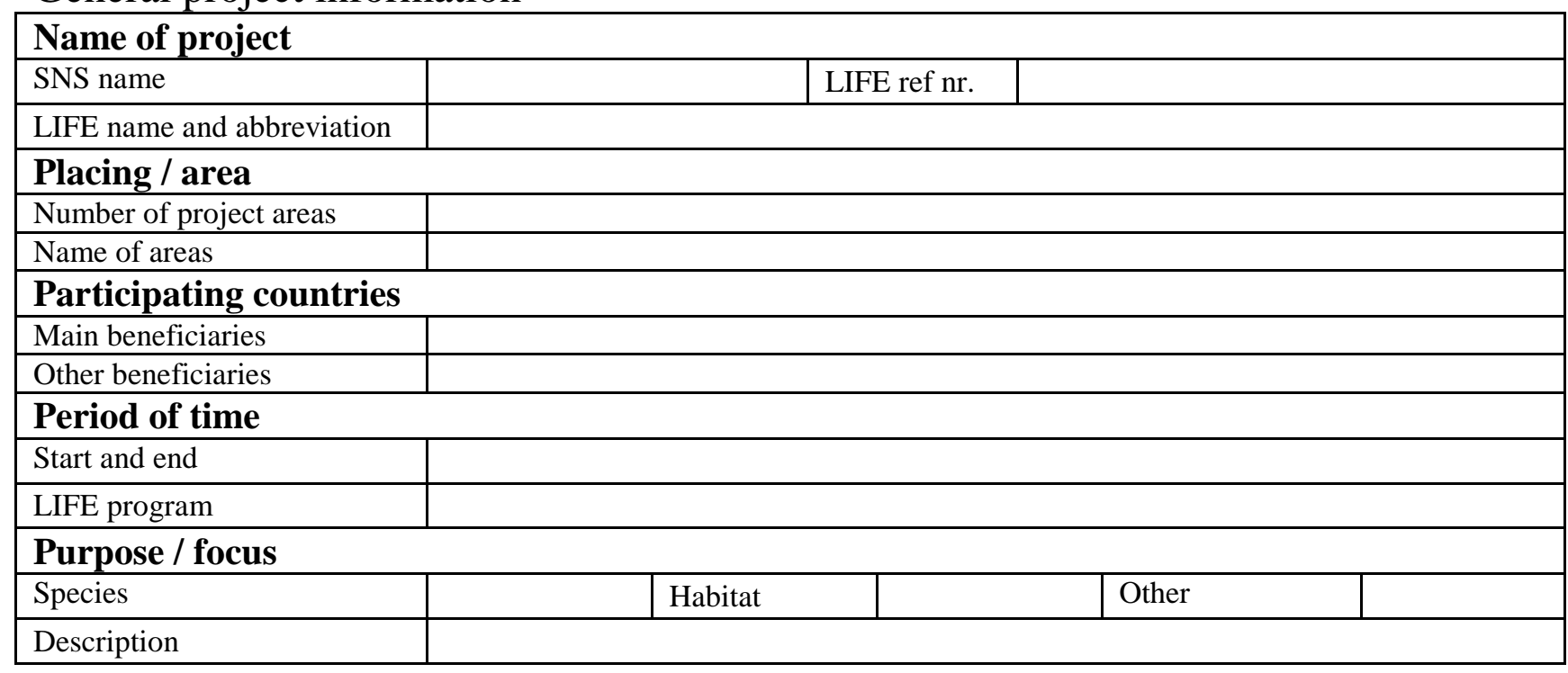

Comparison with the attributes of the SER Primer

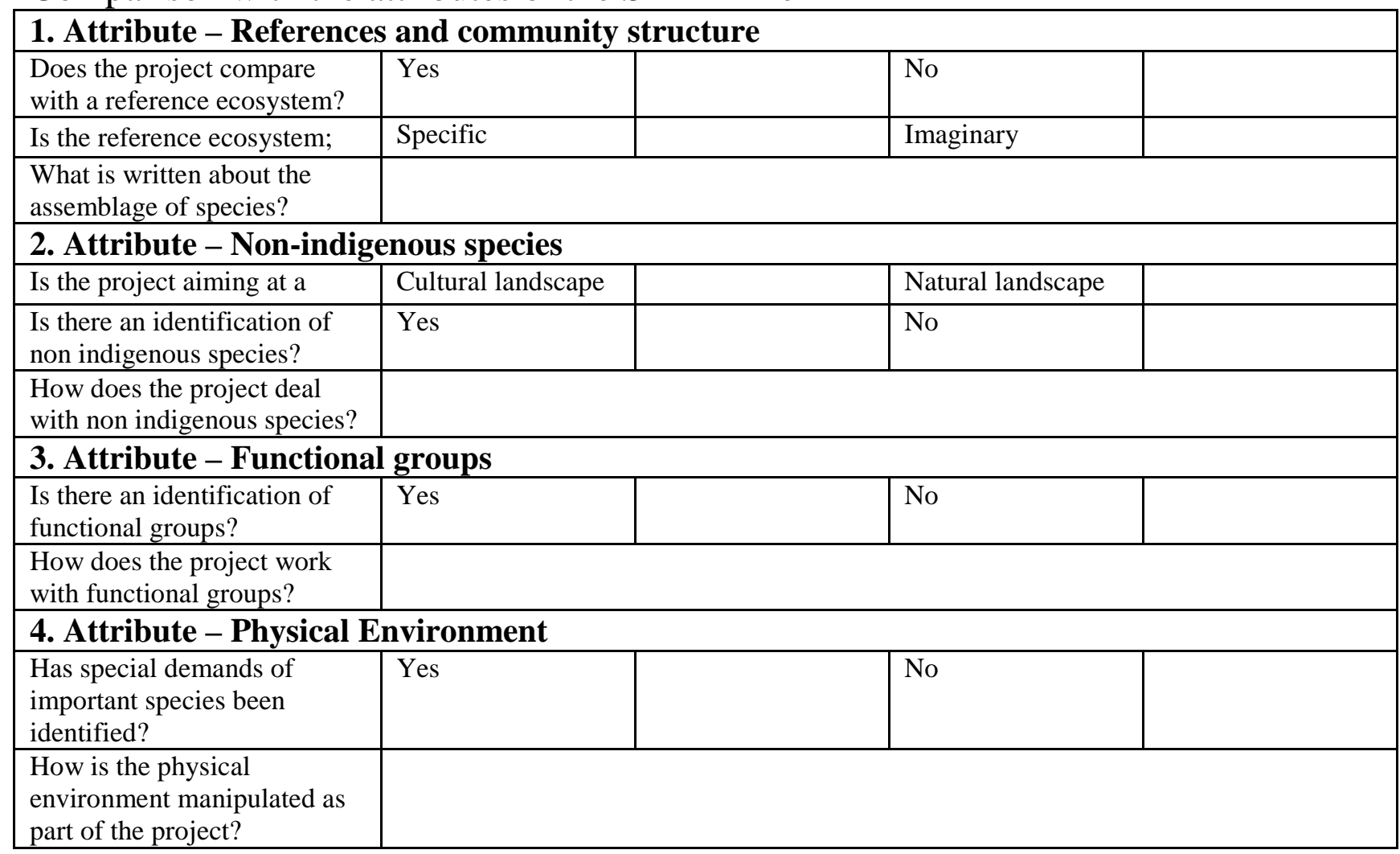




\begin{tabular}{|c|c|c|c|}
\hline \multicolumn{4}{|c|}{ 5. Attribute - Functioning ecosystem } \\
\hline $\begin{array}{l}\text { Has ecosystem functions } \\
\text { been identified? }\end{array}$ & Yes & No & \\
\hline \multicolumn{4}{|l|}{$\begin{array}{l}\text { What is written about } \\
\text { ecosystem functions? }\end{array}$} \\
\hline $\begin{array}{l}\text { Has prospective dysfunctions } \\
\text { been identified? }\end{array}$ & Yes & No & \\
\hline \multicolumn{4}{|c|}{\begin{tabular}{|l|l} 
How does the project deal & \\
with prospective & \\
dysfunctions? & \\
\end{tabular}} \\
\hline \multicolumn{4}{|c|}{ 6. Attribute - Larger ecological matrix } \\
\hline $\begin{array}{l}\text { Is the project area part of a } \\
\text { larger ecological network? }\end{array}$ & Yes & No & \\
\hline \multicolumn{4}{|c|}{\begin{tabular}{|l|l} 
What is written about & \\
ecological connectivity? & \\
\end{tabular}} \\
\hline \multicolumn{4}{|c|}{ 7. Attribute - External threats } \\
\hline $\begin{array}{l}\text { Has external threats and their } \\
\text { sources been identified? }\end{array}$ & Yes & No & \\
\hline \multicolumn{4}{|l|}{$\begin{array}{l}\text { What is done to eliminate } \\
\text { external threats? }\end{array}$} \\
\hline \multicolumn{4}{|l|}{ 8. Attribute - Resilience } \\
\hline \multicolumn{4}{|l|}{$\begin{array}{l}\text { What is written about normal } \\
\text { periodic stress events, and the } \\
\text { ability of the restored } \\
\text { ecosystem to recover from } \\
\text { such? }\end{array}$} \\
\hline \multicolumn{4}{|c|}{ 9. Attribute - Self-sustainability and ecosystem development } \\
\hline Does the project aim at; & $\begin{array}{l}\text { Maintaining a } \\
\text { certain type of } \\
\text { nature with defined } \\
\text { spectrum of } \\
\text { species? }\end{array}$ & $\begin{array}{l}\text { Enabling natural } \\
\text { processes to } \\
\text { develop, with } \\
\text { acceptance of } \\
\text { changed species } \\
\text { composition, } \\
\text { appearance etc.? }\end{array}$ & \\
\hline $\begin{array}{l}\text { Does the project include } \\
\text { defined recurring } \\
\text { management? }\end{array}$ & Yes & No & \\
\hline \multicolumn{4}{|l|}{$\begin{array}{l}\text { If so, what does the defined } \\
\text { recurring management } \\
\text { include? }\end{array}$} \\
\hline $\begin{array}{l}\text { Does the project include } \\
\text { possibility for adaptive } \\
\text { management which is not yet } \\
\text { defined? }\end{array}$ & Yes & No & \\
\hline $\begin{array}{l}\text { Is the recurring and/or } \\
\text { adaptive management } \\
\text { included in order to; }\end{array}$ & $\begin{array}{l}\text { Maintaining a } \\
\text { certain type of } \\
\text { nature with defined } \\
\text { spectrum of } \\
\text { species? }\end{array}$ & $\begin{array}{l}\text { Enabling natural } \\
\text { processes to } \\
\text { develop, with } \\
\text { acceptance of } \\
\text { changed species } \\
\text { composition, } \\
\text { appearance etc.? }\end{array}$ & \\
\hline
\end{tabular}

